\title{
3D Ore Characterization as a Paradigm Shift for Process Design and Simulation in Mineral Processing
}

\author{
Pratama Istiadi Guntoro ${ }^{1,2}$, Yousef Ghorbani', and Jan Rosenkranz' \\ 'Division of Minerals and Metallurgical Engineering, Luleå University of Technology, Luleå, Sweden \\ ${ }^{2}$ Kaunis Iron AB, Pajala, Sweden
}

Received July 7, 2021; accepted July 19, 2021; published online August 16, 2021

\begin{abstract}
Current advances and developments in automated mineralogy have made it a crucial key technology in the field of process mineralogy, allowing better understanding and connection between mineralogy and the beneficiation process. The latest developments in X-ray micro-computed tomography $(\mu \mathrm{CT})$ have shown a great potential to let it become the next-generation automated mineralogy technique. $\mu \mathrm{CT}$ 's main benefit lies in its capability to allow 3D monitoring of the internal structure of the ore sample at resolutions down to a few hundred nanometers, thus excluding the common stereological error in conventional 2D analysis. Driven by the technological and computational progress, $\mu \mathrm{CT}$ is constantly developing as an analysis tool and successively it will become an essential technique in the field of process mineralogy. This study aims to assess the potential application of $\mu \mathrm{CT}$ systems, for $3 \mathrm{D}$ ore characterization through relevant case studies. The opportunities and platforms that $\mu \mathrm{CT} 3 \mathrm{D}$ ore characterization provides for process design and simulation in mineral processing are presented.
\end{abstract}

Keywords: X-ray microcomputed tomography, Mineralogy, Texture, Liberation, Geometallurgy

3D-Erzcharakterisierung als Paradigmenwechsel für Prozessentwurf und Simulation in der Mineralaufbereitung

Zusammenfassung: Aktuelle Fortschritte und Entwicklungen in der automatisierten Mineralogie haben diese zu einer wesentlichen Schlüsseltechnologie im Bereich der Prozessmineralogie gemacht, die ein besseres Verständnis und eine bessere Verknüpfung zwischen Mineralogie und dem Aufbereitungsprozess ermöglicht. Neueste Entwicklungen in der Mikro-Röntgen-Computertomographie

Prof. Dr.-Ing. J. Rosenkranz ( $\square$ )

Division of Minerals and Metallurgical Engineering,

Luleå University of Technology,

SE-971 87 Luleå, Sweden

jan.rosenkranz@Itu.se $(\mu \mathrm{CT})$ haben gezeigt, dass sie ein großes Potenzial haben, die zukünftige automatisierte Mineralogietechnik zu werden. Der Hauptvorteil der $\mu \mathrm{CT}$ liegt in ihrer Fähigkeit, eine 3D-Verfolgung der inneren Struktur einer Erzprobe mit Auflösungen bis hinunter zu einigen hundert Nanometern zu ermöglichen, wodurch der übliche stereologische Fehler bei der konventionellen 2D-Analyse ausgeschlossen wird. Angetrieben durch den technologischen und rechnentechnischen Fortschritt entwickelt sich $\mu$ CT als Analysewerkzeug ständig weiter und wird sukzessive zu einer unverzichtbaren Technik im Bereich der Prozessmineralogie. Diese Studie zielt darauf ab, die potenzielle Anwendung des $\mu$ CT-Systems für die 3D-Erzcharakterisierung durch relevante Fallstudien zu beurteilen. Die Möglichkeiten und Plattformen, die die $\mu \mathrm{CT}$ 3D-Erzcharakterisierung für Prozessdesign und Simulation in der Mineralaufbereitung bietet, werden vorgestellt.

Schlüsselwörter: Mikro-Röntgen-Computertomographie, Mineralogie, Mikrostruktur, Aufschluß, Geometallurgie

\section{Introduction}

The heterogeneous nature of the plant ore feed imposes a challenge for a better understanding of mineral processing operations. Such an understanding is important in the design and optimization of mineral processing flowsheets. Furthermore, with the increasingly complex ore bodies and stricter environmental requirements, an optimal production planning for an ore beneficiation plant is becoming ever more crucial.

Process modeling and simulation are common tools used to help engineers in production planning. Such tools usually include a set of mathematical equations for describing the mineral processing operations. The models take ore data and process control parameters as an input and predict the mineral processing performance as the output. The performance can be described through various parameters, such as recovery, product grade, par- 


\begin{tabular}{|ll|}
\hline $\begin{array}{l}\text { TABLE 1 } \\
\text { Level of details of information in process modeling. } \\
\text { (Parian et al. [1]) }\end{array}$ \\
\hline $\begin{array}{l}\text { Level of } \\
\text { details }\end{array}$ & Explanation \\
\hline Bulk & $\begin{array}{l}\text { The ore particles in the stream behave identically } \\
\text { regardless of their particle size and liberation. } \\
\text { Solid flowrate, mineralogical and chemical as- } \\
\text { says that affect the process performance }\end{array}$ \\
\hline Sized & $\begin{array}{l}\text { Same as bulk but includes particle size classes. } \\
\text { This allows the definition of solid flowrate and } \\
\text { assays for each size class in the stream }\end{array}$ \\
\hline $\begin{array}{l}\text { Sized } \\
\text { by liber- } \\
\text { ation }\end{array}$ & $\begin{array}{l}\text { Same as sized but also includes liberation } \\
\text { classes for each size class. The solid flowrate } \\
\text { and assays can then be defined for each size } \\
\text { class and liberation class }\end{array}$ \\
\hline
\end{tabular}

ticle size distribution, waste generation, as well as energy consumption.

Depending on the level of detail in the process modeling and simulation, the approaches can consider either the whole process or each unit operation as separate units. The former usually use simple equations to predict the performance of the entire process, also denoted as "black-box" model. On the other hand, detailed models for unit operations can be useful particularly in comminution circuits when one needs to consider the energy consumption of the grinding operation [1, 2].

As mentioned earlier about the heterogeneous nature of the ore feed, process models can be classified also depending on the available information about the feed ore. The properties of the feed ore that can be used for process models are total solids, chemical and mineralogical assays, as well as particle properties (size and mineral liberation) [1]. These properties can be made available in the bulk stream or even be split into sub-streams depending on the size classes and liberation classes. This is summarized in Table 1.

\subsection{Automated Mineralogy in Process Modeling}

With the advancement of automated mineralogical tools such as Quantitative Evaluations of Minerals by Scanning Electron Microscopy (QEMSCAN) [3] and Mineral Liberation Analyzer (MLA) [4], the incorporation of mineralogical and liberation information in process modeling has become more feasible. This allows for the most detailed level of process modeling, namely sized by liberation (Table 1).

Automated mineralogical tools can generate a population of mineral particles containing information about the mineralogical and liberation which in turn can be used to evaluate the ore beneficiation process. Data reconciliation and mass balancing techniques have also been developed so that particle populations can be reconciled with the assays and solid flowrate $[5,6]$. Some simulation platforms, such as the HSC Chemistry Sim module developed by Metso Outotec, allow the usage of particle data generated by automated mineralogical tools in mass balancing [7] using the aforementioned reconciliation routines.

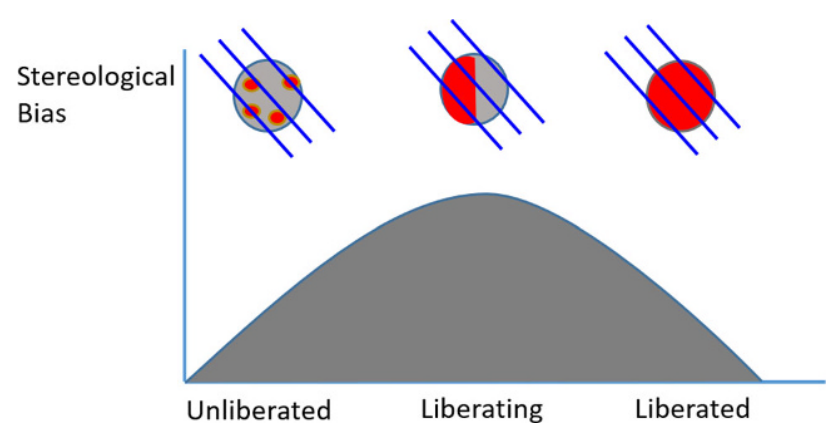

Fig. 1: The effect of stereological bias with different degree of liberation [9]. Possible cross-sections are indicated by the blue lines crossing the particles

\subsection{The Problem of Stereology}

Automated mineralogy offers a rapid and quantitative mineralogical and liberation data acquisition. However, there is a weakness in this technique as there is a loss of dimensionality. Mineral particles are 3D objects, while automated mineralogical tools can only produce a $2 \mathrm{D}$ cross section of the ore samples. This loss of dimensionality can lead to an overestimation in mineral liberation as the cross section is not the actual representation of the particles [8], as represented in Fig. 1.

Stereological issues can be addressed with numerous stereological correction techniques [8-11], which estimate the 3D mineral liberation based on 2D mineral liberation. These stereological correction techniques are barely applied in practice, and their applicability to different types of ore particles have not yet been studied extensively [10]. Increasing the number of particles in the analysis will increase the statistical reliability of the mineral liberation analysis but will not completely eliminate the stereological error [12].

The stereological error issues are more prevalent in multimineral systems, which is often the case in mineral beneficiation processes [10]. The complexity of addressing stereological error in mineral process simulation and mass balancing has been raised by dos Santos and Galery [13]. It was argued that, due to the interdependencies of the liberation data with the mass balance reconciled assay data, the stereologically corrected liberation data would most likely be incompatible with the reconciled assay data.

\subsection{D Ore Characterization with X-ray Microcomputed Tomography}

Over the last decades, the development of X-ray Microcomputed Tomography $(\mu \mathrm{CT})$ in geosciences has created a potential for 3D ore characterization free from stereological errors. Several studies have been devoted to evaluating the potential application of $\mu \mathrm{CT}$ for mineral characterization [14-17].

The $\mu \mathrm{CT}$ system has shown to be capable of extracting 3D ore features such as mineralogy and mineral liberation 
Fig. 2: Ore feature extraction using $\mu \mathrm{CT}$. The $\mathrm{X}$-ray source originates from a small focal spot and illuminates a planar detector. The projections are reconstructed to $\mu \mathrm{CT}$ images (slices) which are then stacked to 3D image of the ore sample. The stacked 3D images are often the raw data for further data processing and feature extraction

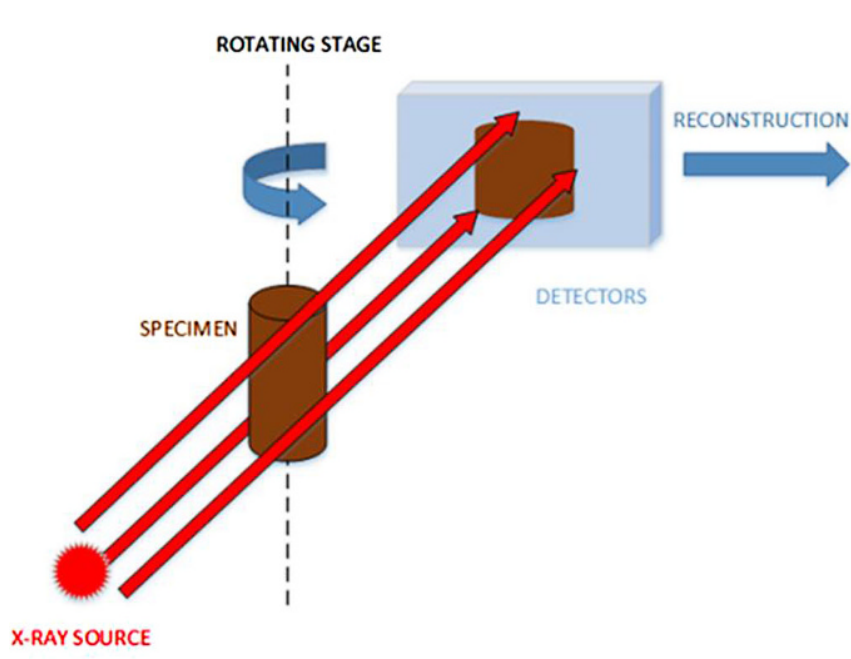

PROJ ECTION IMAGES / SLICES

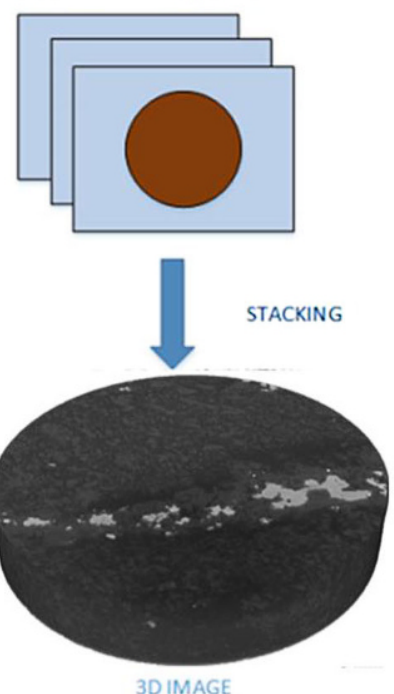

[18-20], particle morphology [21], as well as ore texture [14, 22]. Furthermore, with the additional depth of information offered by $\mu C T$ systems, some other ore features such as mineral surface exposure $[23,24]$ can also be extracted.

This study seeks to evaluate the potential application of $\mu C T$ systems, in particular a laboratory cone beam scanning configuration, for 3D ore characterization, especially in relation to process design and simulation. Relevant case studies are discussed in this study.

\section{Principles of 3D Ore Characterization with $\mu \mathrm{CT}$}

The configuration of the $\mu \mathrm{CT}$ system is shown in Fig. 2. During acquisition, the ore sample is exposed to the incident X-ray beam and rotated $180^{\circ}$ to obtain a number of projections. The projections are then reconstructed to create $2 \mathrm{D}$ projection images of the measured ore volume. The pixels in the 2D projection images have the spatial information of the measured sample so that these 2D images can be stacked into a 3D volume. The 3D volume can then be rendered for visualization on 2D screens or alternatively further processed as the "raw data" for feature extraction (size, shape, mineralogy) of the sample.

The $\mu$ CT system acquires the differences of X-ray attenuation of the different mineral phases in the ore sample. The attenuation of the mineral phases depends on the atomic number and the density of the mineral. Using different energy levels of the beam will affect the sensitivity of the attenuation to the density and atomic number. The higher energy of the beam will render the attenuation more dependent on density. This creates difficulties as many minerals have a similar density. On the lower energy spectra, the attenuation will be more sensitive to the atomic number; therefore, it would be easier to segment the mineral phases. Nevertheless, the lower energy of the beam would mean a longer exposure time to achieve a good signal-tonoise ratio.

\section{3D Mineralogical Analysis with $\mu \mathrm{CT}$}

The mineralogical analysis using $\mu \mathrm{CT}$ often involves image-processing techniques to differentiate the minerals in the $3 \mathrm{D}$ volume based on the voxel grayscale values, which correspond to the attenuation coefficient of the mineral phases. Several image-processing techniques are quite popular with regard to mineral segmentation using $\mu \mathrm{CT}$. Some case studies with respect to these techniques are discussed in this section.

When dealing with intact core samples, the initial segmentation between the pores and rock matrix are rather straightforward, as techniques such as simple Otsu thresholding has been applied [25]. Furthermore, the subsequent mineral segmentation between the gangue minerals and "valuable" minerals (often higher in density) is also rather straightforward, with multiple techniques available [26, 27].

Further complications arise when differentiating minerals of similar properties (density and/or atomic number). This is the main challenge with $\mu \mathrm{CT}$ as a mineralogical analysis tool compared to 2D-based automated mineralogy, as no information about the chemical composition of the phases is available to determine the mineralogy of the various phases in the core sample.

Several researchers have proposed a cross-correlation technique between SEM-EDS automated mineralogy and $\mu \mathrm{CT}[18,19]$, an example being shown in Fig. 3. The proposed techniques could help $\mu \mathrm{CT}$ systems in differentiating minerals with similar properties, such as pyrite and chalcopyrite, copper sulfides minerals, and more. Others have proposed calibrating the $\mu \mathrm{CT}$ system with pure minerals [28] or optimization of scanning energies [29, 30]. The latter mentioned techniques are post-processing techniques, namely techniques that seek to optimize the data acquisition process, instead of the data processing sequences. 
Fig. 3: Example of cross-correlation between SEM-EDS data and $\mu$ CT data, showing the alignment of the SEM-EDS image slice with the $\mu$ CT slice. After alignment, the mineralogy of the $\mu C T$ slice can be inferred from the SEM-EDS data
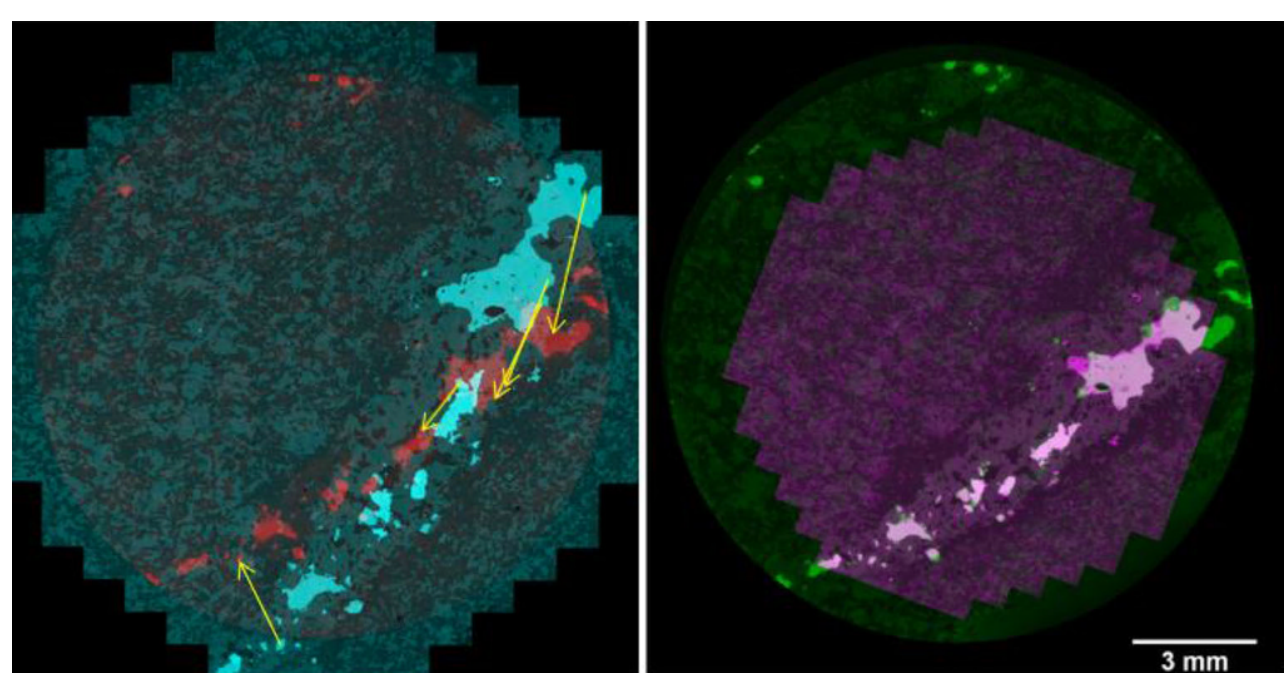

\section{3D Ore Texture Analysis}

It can be argued that one of the significant advantages of the $\mu \mathrm{CT}$ system is that it is relatively free from sample preparation as compared to $2 \mathrm{D}$ automated mineralogy. When dealing with core samples, $\mu \mathrm{CT}$ offers an in-depth analysis technique to acquire mineralogical and texture information of the core sample. As with the development of the use of computer vision and image analysis to quantify ore texture of core samples [31-33], $\mu \mathrm{CT}$ offers a yet new alternative in acquiring $3 \mathrm{D}$ ore texture.

The potential application of $\mu \mathrm{CT}$ in drill core texture analysis has been subject of several investigations [14, 22, 34]. The principles of texture analysis used in these studies are quite commonplace in image processing communities, as such texture analysis is often used in face pattern recognition [35].

The development towards quantitative ore texture analysis is essential in process modelling as it has been shown that ore texture affects the behavior of the ore in the beneficiation process. Pérez-Barnuevo et al. [36] have shown that the drill cores that are often misclassified in the automated texture recognition routines ultimately behave similarly in the laboratory tests. Guntoro et al. [20] have demonstrated that drill cores that were classified into different texture classes using automated 3D texture recognition routines have a different breakage patterns and are therefore affecting the mineral liberation (and subsequently the behavior in separation processes).

The aforementioned cases describe the potentials of quantitative texture classification into discrete classes, in which each class is expected to behave differently in the beneficiation process. However, the future development of quantitative texture analysis should create the potential for incorporating continuous textural descriptors in the process models, rather than descriptors based on discrete classes. This would then result in models similar to first order kinetics models for assays in the flotation process but using texture rather than assays. Such a development would fully incorporate the mineralogy and texture in process modeling and simulation.

\section{3D Mineral Liberation and Process Simulation}

The previous sections primarily described the use of $\mu \mathrm{CT}$ for drill core samples. Automated mineralogy mostly deals with particulate samples, in which the particle data can then be used for process simulation. There have been several studies on using $\mu \mathrm{CT}$ for mineral liberation analysis [19, 37, 38]. These studies are, however, limited in their mineralogical definition of the samples as compared to a traditional SEM-EDS mineral liberation analysis. For example, the $\mu \mathrm{CT}$ analysis in these studies simplified the gangue mineralogy as one group of gangue minerals. This can pose challenges as some beneficiation processes are significantly affected by the type of gangue minerals, such as those employed in trace and refractory ores like gold and platinum group element ores [39].

Other challenges in dealing with particulate samples include the partial voxel effect in which this effect is more pronounced in the boundaries between the mineral phases. This creates a gradient boundary instead of a sharp boundary, making the mineral quantification uncertain. Several corrections for this bias have been developed [40, 41]. Furthermore, there are also challenges with the limited spatial resolution, as typical $\mu C T$ systems have spatial resolutions ranging from $10-50 \mu \mathrm{m}$ [42], which makes it challenging to analyze small grains in that particle size range. Nevertheless, some newer $\mu \mathrm{CT}$ systems can go below $1 \mu \mathrm{m}$ (sub$\mu \mathrm{CT}$ ) [43], which makes it possible to analyze small grains, but at the expense of exposure time and sample size.

Another approach used simulated 3D liberation ([20,44]; Fig. 4), in which the resulting particle data can be used in process simulation. Such a simulated liberation can avoid the complications in dealing with a particulate sample, but a calibration of the liberation model is still required to build an accurate liberation model. 


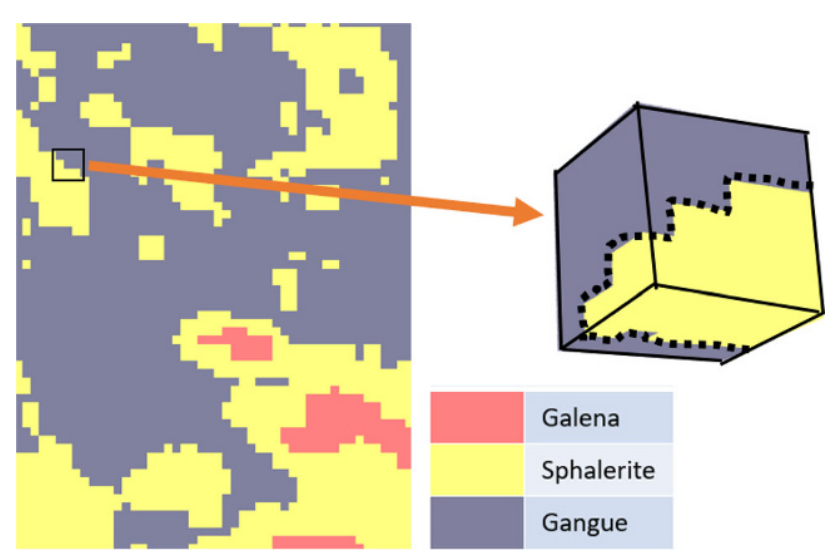

Fig. 4: Example of liberation simulation from core texture as in Guntoro et al. [20]. A population of simulated 3D particles are "sampled" from the core image

\section{Conclusions}

The following conclusions can be made with respect to the application of $\mu \mathrm{CT}$ for $3 \mathrm{D}$ ore characterization:

1. While advanced image processing techniques of the $\mu \mathrm{CT}$ images can help in mineralogical analysis, the path forward should focus more on the optimization of the acquisition system as well as scanning conditions so that simple image processing techniques can be used instead for mineralogical analysis. The development of multiple detector systems, such as a combination of $\mu \mathrm{CT}$ with X-ray Diffraction or X-ray Fluorescence, can be an interesting way forward $[45,46]$.

2. The potential application of $\mu \mathrm{CT}$ in drill core texture analysis is certainly quite promising as here lies the main advantage of such a system with less sample preparatory work and the huge amount of data that it generates, even including texture-based simulated particle data for process simulation. Further studies on incorporating the quantitative ore texture analysis techniques with the process models should be conducted.

3. A further optimization in the reconstruction and postprocessing techniques for $\mu \mathrm{CT}$ system could also help alleviate the problems in using $\mu \mathrm{CT}$ for particulate samples. Coupled with technological developments towards nano-scale $\mu \mathrm{CT}$, the application of $\mu \mathrm{CT}$ for particulate samples and mineral liberation analysis could become more feasible.

Acknowledgements. This study received funding from the European Union's Horizon 2020 research and innovation program under grant agreement No. 722677 , as part of the Metallntelligence network (www.metalintelligence.eu).

Funding. Open access funding provided by Lulea University of Technology.

Open Access This article is licensed under a Creative Commons Attribution 4.0 International License, which permits use, sharing, adaptation, distribution and reproduction in any medium or format, as long as you give appropriate credit to the original author(s) and the source, provide a link to the Creative Commons licence, and indicate if changes were made. The images or other third party material in this article are included in the article's Creative Commons licence, unless indicated otherwise in a credit line to the material. If material is not included in the article's Creative Commons licence and your intended use is not permitted by statutory regulation or exceeds the permitted use, you will need to obtain permission directly from the copyright holder. To view a copy of this licence, visit http://creativecommons.org/licenses/by/4.0/.

\section{References}

1. Parian, M.; Lamberg, P.; Rosenkranz, J.: Process simulations in mineralogy-based geometallurgy of iron ores, Mineral Processing and Extractive Metallurgy, 2018, VOL. 130. NO 1, pp. 25-30. https://doi. org/10.1080/25726641.2018.1507072.

2. Quintanilla, P.; Neethling, S. J.; Brito-Parada, P. R.: Modelling for froth flotation control: A review, Minerals Engineering, 162 (2021), p. 106718

3. Gottlieb, P.; Wilkie, G.; Sutherland, D.; Ho-Tun, E.; Suthers, S.; Perera, K.; Jenkins, B.; Spencer, S.; Butcher, A.; Rayner, J.: Using quantitative electron microscopy for process mineralogy applications, JOM, 52 (2000), pp. 24-25.

4. Fandrich, R.; Gu, Y.; Burrows, D.; Moeller, K.: Modern SEM-based mineral liberation analysis, International Journal of Mineral Processing, 84 (2007), pp. 310-320.

5. Lamberg, P.; Vianna, S.: A technique for tracking multiphase mineral particles in flotation circuits, in Meeting of the Southern Hemisphere on Mineral Technology: 20/11/2007-24/11/2007, (2007), Universidade Federal de Ouro Preto, 2007, pp. 195-202.

6. Savassi, O. N.: Estimating the recovery of size-liberation classes in industrial flotation cells: A simple technique for minimizing the propagation of the experimental error, International Journal of Mineral Processing, 78 (2006), pp. 85-92.

7. Huaman Mamani, L. E.: Evaluating rougher-scavenger flotation circuits using geometallurgical particle-based approach, Independen (2020). Department of Civil, Environmental and Natural Resources Engineering, Luleå University of Technology, 2020.

8. Lätti, D.; Adair, B. J. I.: An assessment of stereological adjustment procedures, Minerals Engineering, 14 (2001), pp. 1579-1587.

9. Spencer, S.; Sutherland, D.: Stereological correction of mineral liberation grade distributions estimated by single sectioning of particles, Image Anal. Stereol., 19 (2000), pp. 175-182.

10. Ueda, T.; Oki, T.; Koyanaka, S.: A general quantification method for addressing stereological bias in mineral liberation assessment in terms of volume fraction and size of mineral phase, Minerals Engineering, 119 (2018), pp. 156-165.

11. Ueda, T.; Oki, T.; Koyanaka, S.: Numerical analysis of the general characteristics of stereological bias in surface liberation assessment of ore particles, Advanced Powder Technology, 29 (2018), pp. 3327-3335.

12. Ueda, T.; Oki, T.; Koyanaka, S.: Statistical effect of sampling particle number on mineral liberation assessment, Minerals Engineering, 98 (2016), pp. 204-212.

13. dos Santos, N. A.; Galery, R.: Modelling flotation per size liberation class-Part 1-Minimizing the propagation of experimental errors in the estimate of flotation recovery, Minerals Engineering, 128 (2018), pp. 254-265.

14. Guntoro, P. I.; Ghorbani, Y.; Butcher, A. R.; Kuva, J.; Rosenkranz, J.: Textural Quantification and Classification of Drill Cores for Geometallurgy: Moving Toward 3D with X-ray Microcomputed Tomography $(\mu \mathrm{CT})$, Natural Resources Research 29, 3547-3565 (2020). https://doi. org/10.1007/s11053-020-09685-5

15. Miller, J. D.; Lin, C. L.; Cortes, A. B.: A review of X-ray computed tomography and its applications in mineral processing, Mineral Procesing and Extractive Metallurgy Review, 7 (1990), pp. 1-18.

16. Lin, C. L.; Miller, J. D.: Cone beam X-ray microtomography for three-dimensional liberation analysis in the 21st century, International Journal of Mineral Processing, 47 (1996), pp. 61-73.

17. Kyle, J. R.; Ketcham, R. A.: Application of high resolution X-ray computed tomography to mineral deposit origin, evaluation, and processing, Ore Geology Reviews, 65 (2015), pp. 821-839.

18. Guntoro, P. I.; Tiu, G.; Ghorbani, Y.; Lund, C.; Rosenkranz, J.: Application of machine learning techniques in mineral phase segmenta- 
tion for X-ray microcomputed tomography $(\mu \mathrm{CT})$ data, Minerals Engineering, 142 (2019). https://doi.org/10.1016/j.mineng.2019.105882

19. Reyes, F; Lin, Q.; Udoudo, O.; Dodds, C.; Lee, P. D.; Neethling, S. J.: Calibrated $\mathrm{X}$-ray micro-tomography for mineral ore quantification, Minerals Engineering, 110 (2017), pp. 122-130.

20. Guntoro, P. I.; Ghorbani, Y.; Parian, M.; Butcher, A. R.; Kuva, J.; Rosenkranz, J.: Development and experimental validation of a texture-based 3D liberation model, Minerals Engineering, 164 (2021), p. 106828.

21. Lin, C. L.; Miller, J. D.: 3D characterization and analysis of particle shape using X-ray microtomography (XMT), Powder Technology 154 (2005), pp. 61-69, 2005

22. Jardine, M.A.; Miller, J. A.; Becker, M.: Coupled X-ray computed tomography and grey level co-occurrence matrices as a method for quantification of mineralogy and texture in $3 \mathrm{D}$, Computers and Geosciences, 111 (2018), pp. 105-117.

23. Fagan-Endres, M. A.; Cilliers, J. J.; Sederman, A. J.; Harrison, S. T. L.: Spatial variations in leaching of a low-grade, low-porosity chalcopyrite ore identified using $\mathrm{X}$-ray $\mu \mathrm{CT}$, Minerals Engineering, 105 (2017), pp. 63-68.

24. Reyes, F; Cilliers, J. J.; Neethling, S. J.: Quantifying mineral liberation by grade and surface exposure using $\mathrm{X}$-ray micro-tomography for flotation processes, in 29th International Mineral Processing Congress, IMPC, (2019), Moscow: Canadian Institute of Mining, Metallurgy and Petroleum, 2019.

25. Yang, B.; Wu, A.; Narsilio, G. A.; Miao, X.; Wu, S.: Use of highresolution $\mathrm{X}$-ray computed tomography and $3 \mathrm{D}$ image analysis to quantify mineral dissemination and pore space in oxide copper ore particles, International Journal of Minerals, Metallurgy, and Materials, 24 (2017), pp. 965-973.

26. Lin, Q.; Neethling, S. J.; Dobson, K. J.; Courtois, L.; Lee, P. D.: Quantifying and minimising systematic and random errors in $\mathrm{X}$-ray micro-tomography based volume measurements, Computers \& Geosciences, 77 (2015), pp. 1-7.

27. Lin, Q.; Barker, D. J.; Dobson, K. J.; Lee, P. D.; Neethling, S. J.: Modelling particle scale leach kinetics based on $\mathrm{X}$-ray computed microtomography images, Hydrometallurgy, 162 (2016), pp. 25-36.

28. Ghorbani, Y.; Becker, M.; Petersen, J.; Morar, S. H.; Mainza, A.; Franzidis, J.-P.: Use of $\mathrm{X}$-ray computed tomography to investigate crack distribution and mineral dissemination in sphalerite ore particles, Minerals Engineering, 24 (2011), pp. 1249-1257.

29. Bam, L. C.; Miller, J. A.; Becker, M.; Basson, I. J.: X-ray computed tomography: Practical evaluation of beam hardening in iron ore samples, Minerals Engineering, 131 (2019), pp. 206-215

30. Kyle, J. R.; Mote, A. S.; Ketcham, R. A.: High resolution X-ray computed tomography studies of Grasberg porphyry Cu-Au ores, Papua, Indonesia, Mineralium Deposita, 43 (2008), pp. 519-532.

31. Koch, P.-H. H.; Lund, C.; Rosenkranz, J.: Automated drill core mineralogical characterization method for texture classification and modal mineralogy estimation for geometallurgy, Minerals Engineering, 136 (2019), pp. 99-109.
32. Lobos, R.; Silva, J. F.; Ortiz, J. M.; Díaz, G.; Egaña, A.: Analysis and Classification of Natural Rock Textures based on New Transformbased Features, Mathematical Geosciences, 48 (2016), pp. 835-870.

33. Pérez-Barnuevo, L.; Lévesque, S.; Bazin, C.: Drill core texture as geometallurgical indicator for the Mont-Wright iron ore deposit (Quebec, Canada), Minerals Engineering, 122 (2018), pp. 130-141.

34. Voigt, M. J.; Miller, J.; Bbosa, L.; Govender, R. A.; Bradshaw, D.; Mainza, A.; Becker, M.: Developing a 3D mineral texture quantification method of drill core for geometallurgy, Journal of the Southern African Institute of Mining and Metallurgy, 119 (2019), pp. 347-353.

35. Ahonen, T.; Hadid, A.; Pietikainen, M.: Face description with local binary patterns: Application to face recognition, IEEE Transactions on Pattern Analysis \& Machine Intelligence, 2006, pp. 2037-2041.

36. Pérez-Barnuevo, L.; Lévesque, S.; Bazin, C.: Automated recognition of drill core textures: A geometallurgical tool for mineral processing prediction, Minerals Engineering, 118 (2018), pp. 87-96.

37. Reyes, F; Lin, O.; Cilliers, J. J.; Neethling, S. J.: Quantifying mineral liberation by particle grade and surface exposure using X-ray microCT, Minerals Engineering, 125 (2018), pp. 75-82.

38. Ueda, T.: Experimental validation of a statistical reliability method for the liberation distribution measurement of ore particles, Minerals Engineering, 140 (2019), p. 105880.

39. Parian, M.; Lamberg, P.; Möckel, R.; Rosenkranz, J.: Analysis of mineral grades for geometallurgy: Combined element-to-mineral conversion and quantitative X-ray diffraction, Minerals Engineering, 82 (2015), pp. 25-35.

40. Godinho, J. R. A.; Kern, M.; Renno, A. D.; Gutzmer, J.: Volume quantification in interphase voxels of ore minerals using 3D imaging, Minerals Engineering, 144 (2019), p. 106016.

41. Wang, Y.; Lin, C. L.; Miller, J. D.: Quantitative analysis of exposed grain surface area for multiphase particles using $X$-ray microtomography, Powder Technology, 308 (2017), pp. 368-377.

42. Ducheyne, P.; Healy, K.; Hutmacher, D. W.; Grainger, D. W.; Kirkpatrick, C. J.: Comprehensive Biomaterials II, (2017). Elsevier, 2017.

43. Kastner, J.; Harrer, B.; Requena, G.; Brunke, O.: A comparative study of high resolution cone beam $\mathrm{X}$-ray tomography and synchrotron tomography applied to Fe- and Al-alloys, NDT \& E International, 43 (2010), pp. 599-605.

44. Hilden, M. M.; Powell, M. S.: A geometrical texture model for multimineral liberation prediction, Minerals Engineering, 111 (2017), pp. 25-35.

45. Takahashi, H.; Sugiyama, T.: Application of non-destructive integrated CT-XRD method to investigate alteration of cementitious materials subjected to high temperature and pure water, Construction and Building Materials, 203 (2019), pp. 579-588.

46. Bergqvist, M.; Landström, E.; Hansson, A.; Luth, S.: Access to geological structures, density, minerals and textures through novel combination of 3D tomography, XRF and sample weight, in Australasian Exploration Geoscience Conference, (2019), Perth, Western Australia, 2019, pp. 3-5.

Publisher's Note. Springer Nature remains neutral with regard to jurisdictional claims in published maps and institutional affiliations. 